\title{
Novel Inorganic Membranes for High Temperature Carbon Dioxide Separation
}

Final Technical Report

$09 / 01 / 00$

$08 / 31 / 02$

Jerry Y. S. Lin

DE-FG26-00NT40824

\author{
University of Cincinnati \\ Department of Chemical Engineering \\ Mail Location 171 \\ Cincinnati, OH 45221-0171
}

February, 2003 


\section{DISCLAIMER}

"This report was prepared as an account of work sponsored by an agency of the United States Government. Neither the United States Government nor any agency thereof, nor any of their employees, makes any warranty, express or implied, or assumes any legal liability or responsibility for the accuracy, completeness, or usefulness of any information, apparatus, product, or process disclosed, or represents that its use would not infringe privately owed rights. Reference herein to any specific commercial product, process, or service by trade name, trademark, manufacturer, or otherwise does not necessarily constitute or imply its endorsement, recommendation, or favoring by the United States Government or any agency thereof. The views and opinions of authors expressed herein do not necessarily state or reflect those of the United States Government or any agency thereof." 


\section{CONTENTS}

Disclaims $\quad 2$

Abstract $\quad 4$

Introduction $\quad 5$

$\begin{array}{ll}\text { Experimental } & 6\end{array}$

Results and Discussion $\quad 7$

$\begin{array}{ll}\text { Lithium Zirconate Membranes } & 7\end{array}$

Dual-Phase Membranes $\quad 8$

$\begin{array}{lr}\text { Publications from This Project } & 8\end{array}$

Conclusions $\quad 9$

Literature Cited 9 


\begin{abstract}
We studied feasibility of two types of dense inorganic membranes which are fundamentally different from those porous inorganic membranes reported in the literature for separation of carbon dioxide from gas streams at high temperatures. The first is a symmetric, dense membrane made of $\mathrm{Li}_{2} \mathrm{ZrO}_{3}$ and the second is a dual-phase metal-carbonate membrane. We have identified a unique $\mathrm{CO}_{2}$ sorption/desorption mechanism on lithium zirconate. Considering the all obtained data, we proposed a double layer model to describe the $\mathrm{CO}_{2}$ sorption/desorption behavior of lithium zirconate. In the model, final product after $\mathrm{CO}_{2}$ sorption is a particle which consists of a $\mathrm{ZrO}_{2}$ core inside and a $\mathrm{Li}_{2} \mathrm{CO}_{3}$ shell. The understanding of $\mathrm{CO}_{2}$ sorption mechanisms suggests a means to improve $\mathrm{CO}_{2}$ sorption rate on this group of oxides. It also leads to the conclusion that lithium zirconate is not a suitable material for the proposed dense ceramic membrane for $\mathrm{CO}_{2}$ separation. Following the second concept of dense membrane for $\mathrm{CO}_{2}$ separation, we succeeded in preparing the hermetic (gas-tight) dense inorganic membrane consisting of a porous metal phase and a molten carbonate phase. The metal phase not only provides the mechanical support but also is electronically conducting, reducing the overall mass transfer resistance for $\mathrm{CO}_{2}$ permeation through the membrane. Permeation data showed that nitrogen or helium is not permeable through these membranes (only $\mathrm{CO}_{2}$, with $\mathrm{O}_{2}$, can permeate through the membrane based on the transport mechanism). This dual-phase membrane may offer promising properties for applications in membrane processes for separation of $\mathrm{CO}_{2}$ from flue (or coal gasification gas) at high temperatures $\left(350-550^{\circ} \mathrm{C}\right.$ ).
\end{abstract}




\section{INTRODUCTION}

Efficient separation of carbon dioxide from flue gas is key to carbon dioxide sequestration and control of the greenhouse gas. In this project, we studied feasibility of two types of dense inorganic membranes which are fundamentally different from porous inorganic membranes which have been studied for $\mathrm{CO}_{2}$ separation. The first is a symmetric, dense membrane made of $\mathrm{Li}_{2} \mathrm{ZrO}_{3}$ and the second is a dual-phase metal-carbonate membrane. They were designed for carbon dioxide separation in the temperature range of $400-600^{\circ} \mathrm{C}$.

The first concept was based on a recent study conducted by Nakagawa and Ohashi of Toshiba who reported in a short communication [1] good carbon dioxide sorption properties for $\mathrm{Li}_{2} \mathrm{ZrO}_{3}$ in $500-700^{\circ} \mathrm{C}$. Carbon dioxide sorption capacity is $100 \mathrm{mg} / \mathrm{g}$ at temperature of $600^{\circ} \mathrm{C}$ and $\mathrm{P}_{\mathrm{CO} 2}$ of $0.7 \mathrm{~atm}$. They found that the carbonated sorbent can be regenerated to $\mathrm{Li}_{2} \mathrm{ZrO}_{3}$ by varying the temperature, or by reducing the carbon dioxide pressure. The regenerated ceramic can be used in subsequent sorption steps. Unlike most other oxides that can react with carbon dioxide to form carbonates, the particles made of this ceramic could maintain their mechanical integrity after repeated cycles of carbonation and regeneration. Furthermore, the carbon dioxide sorption capacity of this material is not affected by the presence of water vapor and hydrogen in the gas stream.

A membrane made of $\mathrm{Li}_{2} \mathrm{ZrO}_{3}$, as shown in Figure 1, could be permeable only to carbon dioxide since $\mathrm{Li}_{2} \mathrm{ZrO}_{3}$ only

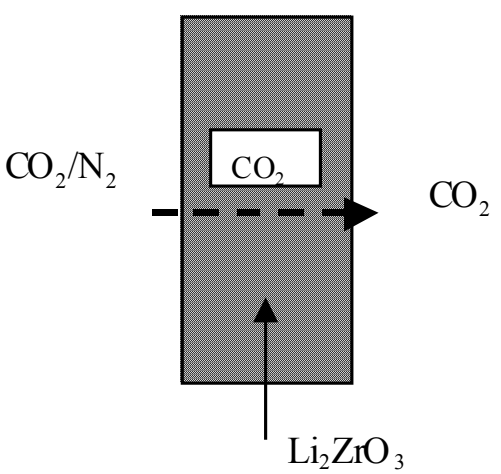

Figure 1 First Concept of Dense Inorganic Membrane Based on $\mathrm{Li}_{2} \mathrm{ZrO}_{3}$ for High Temperature Carbon Dioxide Separation takes carbon dioxide. $\mathrm{Li}_{2} \mathrm{ZrO}_{3}$ meets the following three requirements as the dense membrane material: (1) The material can absorb a considerable amount of carbon dioxide in the bulk of the material in the specified temperature range; (2) The sorption is a reversible, i.e., the sorbed carbon dioxide can be easily desorbed; (3) Sorption of other gases (such as hydrogen) is negligible and the presence of these gases does not affect the sorption of carbon dioxide.

The membrane materials, however, should also meet the other three requirements: (4) membrane with good integrity can be fabricated from this material, (5) the membrane made of this material should be able to maintain good structural and chemical stability under carbon dioxide pressure gradient, and (6) the sorption and desorption processes in this materials should be fast. The research conducted in this project was to study fundamental issues to understand whether $\mathrm{Li}_{2} \mathrm{ZrO}_{3}$ meet these three requirements.

It is known that molten carbonate, such as $\mathrm{Li}_{2} \mathrm{CO}_{3} / \mathrm{K}_{2} \mathrm{CO}_{3}$, can conduct $\mathrm{CO}_{3}{ }^{2-}$ at a very high rate. This is the basis of the molten carbonate fuel cell (MCFC). We also proposed a dual 
phase metal-carbonate membrane for high temperature $\mathrm{CO}_{2}$ separation. This membrane consists of a porous metal phase and a molten carbonate phase, as shown in Figure 2. The metal phase not only serves as a support but also transports electrons. Carbon dioxide separation can be accomplished with the driving force of the $\mathrm{CO}_{2}$ partial pressure gradient. On the upper stream membrane surface $\mathrm{CO}_{2}$, combining with electrons and oxygen, formed $\mathrm{CO}_{3}{ }^{2-}$, which transports through the molten carbonate phase. The $\mathrm{CO}_{3}{ }^{2-}$ releases electrons to form $\mathrm{CO}_{2}$ and $\mathrm{O}_{2}$ on the downstream membrane surface. The electron transports back, through the metal phase, towards the upstream membrane surface. No external electrodes and connector are required in this dual phase membrane. Since only carbon dioxide (with oxygen) can transport through the molten carbonate, the selectivity for $\mathrm{CO}_{2}$ over nitrogen or other gases is theoretically infinite.

The dual-phase metal-carbonate membrane is an extension of the fuel cell concept. This follows the similar approach the inorganic membranologists used for making dense mixedconducting ceramic membranes for oxygen separation, also extended from the concept of the solid

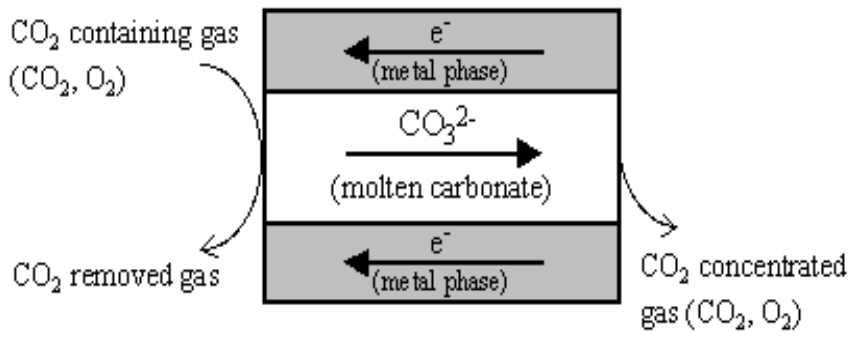
oxide fuel cell. The major uncertainty for the successful development of this dual-phase membrane during the Phase I research was whether a hermetic, stable metal-carbonate dual phase membrane could be fabricated by the direct infiltration method. The research conducted in Phase I was to experimentally verify the synthesis of such dual-phase membrane by a simple synthesis method.

\section{EXPERIMENTAL}

We prepared powders of pure lithium zirconate from lithium carbonate and zirconium oxide by a solid-state method. $\mathrm{CO}_{2}$ sorption properties of the obtained pure $\mathrm{Li}_{2} \mathrm{ZrO}_{3}$ powders were tested by an electronic microbalance and thermogravimetric analysis (TGA). In synthesis of the dual-phase metal-carbonate membrane, 43.5/31.5/25 mole $\% \mathrm{Li} / \mathrm{Na} / \mathrm{K}$ carbonate was used as the molten carbonate. Melting point of $\mathrm{Li} / \mathrm{Na} / \mathrm{K}$ carbonate was $397^{\circ} \mathrm{C}$ and it has a higher $\mathrm{CO}_{3}{ }^{2-}$ ionic conductivity than other carbonates [2]. With the lower melting point as compared to other carbonates, $\mathrm{Li} / \mathrm{Na} / \mathrm{K}$ carbonate membrane could be used at temperatures down to about $400^{\circ} \mathrm{C}$. Porous 316L stainless steel discs (Series 1000, Media Grade 5) from Mott Metallurgy were used as the membrane substrate. The metal membrane is made by compacting metal particles, and it has an average pore diameter of about $3 \mu \mathrm{m}$ and porosity of about $40 \%$. The metal-carbonate dual phase membrane was prepared by the direct infiltration coating method. In this method, one surface of the metal membranes was brought in contact with molten carbonate 
kept at a temperature above its melting point. Gas tightness of the membranes was checked by the unsteady state helium permeation method.

\section{RESULTS AND DISCUSSION}

\section{$\underline{\text { Lithium Zirconate Particles and Membranes }}$}

Figure 3 shows a typical sample weight uptake of the pure $\mathrm{Li}_{2} \mathrm{ZrO}_{3}$ powder at $500^{\circ} \mathrm{C}$ after the surrounding gas is switched from the pure dry air to air containing $50 \% \mathrm{CO}_{2}\left(\mathrm{P}_{\mathrm{CO} 2}=0.5 \mathrm{~atm}\right)$. The figure shows a slow but clear increase in the sample weight. XRD and TGA/DSC analyses suggest that the weight increase corresponds to formation of $\mathrm{Li}_{2} \mathrm{CO}_{3}$ and $\mathrm{ZrO}_{2}$ through reaction between $\mathrm{CO}_{2}$ and $\mathrm{Li}_{2} \mathrm{ZrO}_{3}$. It is clear from the results given in Figure 3 that pure $\mathrm{Li}_{2} \mathrm{ZrO}_{3}$ can absorb $\mathrm{CO}_{2}$ up to around $20 \mathrm{wt} \%$ of its sample weight at $500^{\circ} \mathrm{C}$ within $10,000 \mathrm{~min}$. Although this material has very high $\mathrm{CO}_{2}$ sorption capacity, the sorption rate is low.

The reaction chemistry and the data of $\mathrm{CO}_{2}$ sorption and TGA/DSC, XRD and SEM analyses performed in our laboratory suggest the following sorbent microstructure and mechanism for $\mathrm{CO}_{2}$ sorption on pure $\mathrm{Li}_{2} \mathrm{ZrO}_{3}$ powder, as

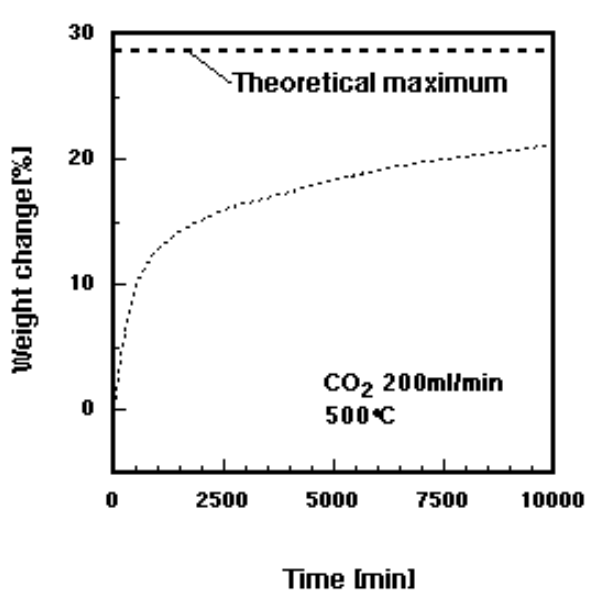

Figure $3 \mathrm{CO}_{2}$ uptake curve of pure shown in Figure 4. The $\mathrm{Li}_{2} \mathrm{ZrO}_{3}$ powders are made of aggregates of about $10 \mu \mathrm{m}$ in size. These aggregates consist of many finer $\mathrm{Li}_{2} \mathrm{ZrO}_{3}$ crystallites of about $0.1-0.5 \mu \mathrm{m}$ in diameter. When these $\mathrm{Li}_{2} \mathrm{ZrO}_{3}$ crystallites are exposed to $\mathrm{CO}_{2}$ at $500^{\circ} \mathrm{C}, \mathrm{CO}_{2}$ molecules move to the surface of the $\mathrm{Li}_{2} \mathrm{ZrO}_{3}$ crystallite and react with $\mathrm{Li}_{2} \mathrm{ZrO}_{3}$ to form solid $\mathrm{ZrO}_{2}$ (monoclinic phase) and $\mathrm{Li}_{2} \mathrm{CO}_{3}$. The initial period of the relative faster increase in the $\mathrm{CO}_{2}$ sorption uptake may correspond to the carbonation process before the formation of a dense $\mathrm{Li}_{2} \mathrm{CO}_{3}$ shell on the outer surface and a dense $\mathrm{ZrO}_{2}$ shell in the middle covering the unreacted $\mathrm{Li}_{2} \mathrm{ZrO}_{3}$ core, as shown in Figure 4. $\mathrm{ZrO}_{2}$ and $\mathrm{Li}_{2} \mathrm{CO}_{3}$ shells are in solid state because their melting points are higher than the temperature for $\mathrm{CO}_{2}$ sorption (melting point of the $\mathrm{Li}_{2} \mathrm{CO}_{3}$ and $\mathrm{ZrO}_{2}$ are respectively $723^{\circ} \mathrm{C}$ and $2700^{\circ} \mathrm{C}$ ). After the formation of the two $\mathrm{Li}_{2} \mathrm{CO}_{3}$ and $\mathrm{ZrO}_{2}$ shells, the carbonation reaction can continue, but at a much slower rate. As shown in Figure 4, $\mathrm{CO}_{2}$ can diffuse through the solid $\mathrm{Li}_{2} \mathrm{CO}_{3}$ shell, and react with $\mathrm{Li}^{+}$and $\mathrm{O}^{2-}$ on the outer surface of the $\mathrm{ZrO}_{2}$ shell.

Another reaction occurs on the surface of the unreacted $\mathrm{Li}_{2} \mathrm{ZrO}_{3}$ to generate $\mathrm{Li}^{+}$and $\mathrm{O}^{2-}$, as indicated in Figure 4. It is well known that $\mathrm{ZrO}_{2}$ contains a considerable number of defects in its crystals including oxygen vacancy $[3,4]$. Oxygen ions can jump through the oxygen vacancy sites and $\mathrm{Li}^{+}$diffuses interstitially through the $\mathrm{ZrO}_{2}$ shell. The carbonation reaction is limited by the solid state transport of $\mathrm{CO}_{2}, \mathrm{Li}^{+}$and $\mathrm{O}^{2-}$ in the $\mathrm{Li}_{2} \mathrm{CO}_{3}$ and $\mathrm{ZrO}_{2}$ shells. Since the sizes of $\mathrm{Li}^{+}$and $\mathrm{O}^{2-}$ ions are much smaller than the molecular size of $\mathrm{CO}_{2}$, the diffusion of $\mathrm{CO}_{2}$ in the 
solid $\mathrm{Li}_{2} \mathrm{CO}_{3}$ layer is expected to be much slower than the diffusion of $\mathrm{Li}^{+}$and $\mathrm{O}^{2-}$ ions in the $\mathrm{ZrO}_{2}$ shell. Therefore the former is more likely to be the rate-limiting step. The diffusion coefficient of $\mathrm{CO}_{2}$ in the solid $\mathrm{Li}_{2} \mathrm{CO}_{3}$ shell, estimated from the $\mathrm{CO}_{2}$ sorption uptake and particle size, is in the order of $10^{-14} \mathrm{~cm}^{2} / \mathrm{s}$ at $500^{\circ} \mathrm{C}$

We found that the rate of $\mathrm{CO}_{2}$ sorption on lithium zirconate can be significantly improved by doping about 10 mole $\% \mathrm{KCO}_{3}$ (with respect to $\mathrm{LiCO}_{3}$ ). The doped $\mathrm{Li}_{2} \mathrm{ZrO}_{3}$ can adsorb 20 wt $\% \mathrm{CO}_{2}$ in $200 \mathrm{~min}$, about 50 times faster than the pure $\mathrm{Li}_{2} \mathrm{ZrO}_{3}$. During carbonation of the doped lithium carbonate the outer shell is $\mathrm{LiCO}_{3}-\mathrm{KCO}_{3}$ which is molten at $500^{\circ} \mathrm{C} . \mathrm{CO}_{2}$ diffuses through the molten carbonate in the case of the doped lithium zirconate, much faster than solid carbonate (pure $\mathrm{LiCO}_{3}$ ) in the case of undoped lithium zirconate. These results suggest that the doped lithium carbonate can be a good sorbent for high temperature carbon dioxide separation. However, the membrane made of either pure and doped lithium zirconate would not function properly. A fresh $\mathrm{Li}_{2} \mathrm{ZrO}_{3}$ membrane, once exposed to $\mathrm{CO}_{2}$ gradient, will convert to $\mathrm{ZrO}_{2}$ and lithium carbonate. This initial step during the use of the membrane is accompanied with phase change and structural rearrangement. The membrane cannot maintain the mechanical integrity for continuous separation of carbon dioxide.

\section{Dual-Phase Membranes}

The metal-carbonate dual phase membrane was prepared by the direct infiltration coating method. It was important to pre-heat the metal substrate in the same furnace as the carbonate. Otherwise, a thick dense carbonate layer could be formed on the surface of, not inside, the metal substrate. The first dipcoating experiment was carried out at $430^{\circ} \mathrm{C}$, slightly higher than the carbonate's melting point. The result looked better than the case without preheating the metal substrate. However, there was still a thin carbonate film covering the surface of the metal substrate. Then, the temperature for the carbonate was raised to

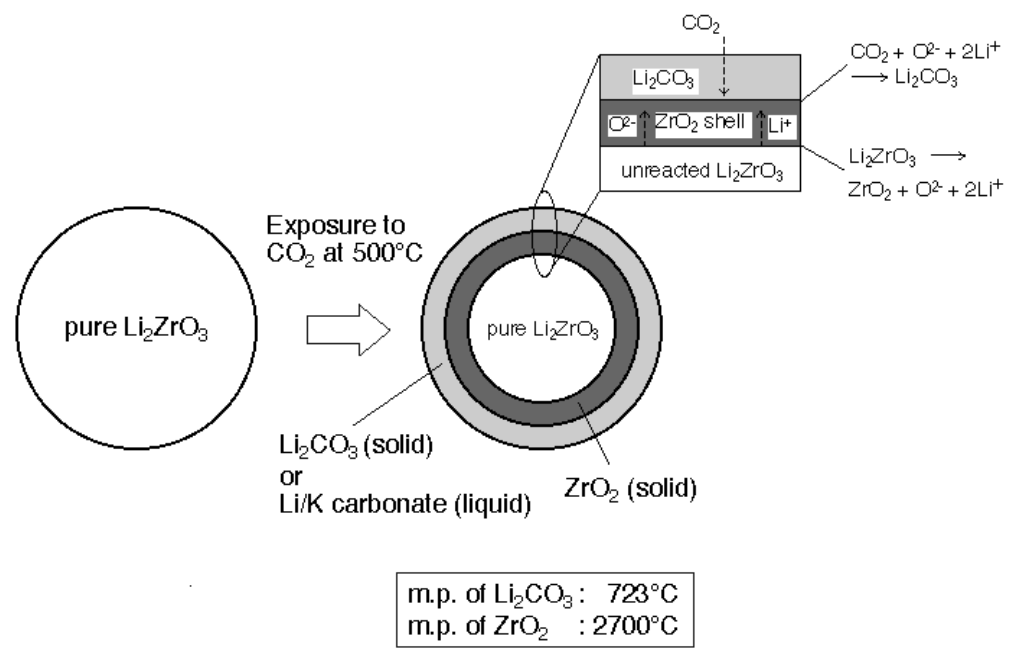

Figure 4 Schematic illustration of carbonation mechanism on $\mathrm{Li}_{2} \mathrm{ZrO}_{3}$ without and with $\mathrm{K}_{2} \mathrm{CO}_{3}$ $500^{\circ} \mathrm{C}$ to reduce viscosity of the molten carbonate. Also the metal substrate was pre-heated for longer pre-heating time $(15 \mathrm{~min})$ at the same temperature. Good dual-phase metal-carbonate membrane was prepared under these conditions. Visual observation indicates that the pores of the metal membrane were completely filled with 
carbonate and there was essentially no carbonate layer covering the metal substrate membrane surface.

The dual-phase membrane was characterized by XRD for phase structure and $\mathrm{He}$ permeation for gas-tightness. XRD analysis clearly shows X-ray diffraction peaks of stainless steel and carbonate. Helium permeance through the dual-phase metal and molten carbonate is much lower than $10^{-10} \mathrm{~mol} / \mathrm{m}^{2}$.s.Pa, more than 6 orders of magnitude lower than that for the original porous metal membrane. This means that the obtained metal-carbonate membrane is very gas-tight and infiltration of metal membrane pore with the molten carbonate was very successful. The infiltrated carbonate can sustain at least 5 bar transmembrane pressure drop. Since helium will not permeate through the membrane and carbon dioxide will transport through the dense molten carbonate by the ionic transport mechanism, the gas-tightness would translate to good permselectivity for carbon dioxide over helium or nitrogen for the dual-phase membrane at high temperatures. Based on the $\mathrm{CO}_{3}{ }{ }$ conductivity data (electronic conductivity is infinite for metals), it is estimated that $\mathrm{CO}^{2}$ permeance of about $1 \times 10^{-7} \mathrm{~mol} / \mathrm{m}^{2} . \mathrm{s} . P a$ can be obtained for this membrane at $500-600^{\circ} \mathrm{C}$.

\section{PUBLICATIONS FROM THIS PROJECT}

The following papers have been prepared summarizing the results obtained from this project:

1. J.-I. Ida and Y.S. Lin, "Mechanism of high temperature $\mathrm{CO}_{2}$ sorption on lithium zirconate", Environmental Science and Technology, in press (2003)

2. J.-I. Ida and Y.S. Lin, "Synthesis and CO2 Sorption Properties of Pure and Modified Lithium Zirconate", Separa. Purif. Technol., Submitted (2003)

3. R. Xiong, J.-I. Ida and Y.S. Lin, "Kinetics of carbon dioxide sorption on potassium doped lithium zirconate", Chem. Engin. Sci., Submitted (2003)

\section{CONCLUSIONS}

The results obtained in this project suggest that the doped lithium carbonate can be a good sorbent for high temperature carbon dioxide separation. However, the membrane made of either pure and doped lithium zirconate would not function properly. We succeeded in synthesizing a hermetic, stable metal-carbonate dual phase membrane consisting of a porous metal phase and a dense molten carbonate. Nitrogen or helium is not permeable through these membranes (only $\mathrm{CO}_{2}$, with $\mathrm{O}_{2}$ can permeate through the membrane based on the transport mechanism). Since only carbon dioxide (with oxygen) can transport through the molten carbonate, the selectivity for $\mathrm{CO}_{2}$ over nitrogen or other gases is theoretically infinite.

\section{LITERATURE CITED}

1. K. Nakagawa and T. Ohashi, J. Electrochem. Soc., 145, 1344 (1998)

2. G. Mamantov, J. Braunstein and C.B. Mamantov, Advances in Molten Salt Chemistry, Vol.4, Plenum Press, New York (1981)

3. R. Stevens, Zirconia and Zirconia Ceramics, Magnesium Elektron Ltd., Twickenham, UK (1986)

4. Y.S. Lin, K.J. de Vries, H.W. Brinkman and A.J. Burggraaf, J. Membrane Sci., 66, 211-226 (1992) 